\title{
VARIANTNÍ PŘÍSTUPY K EKONOMICKÉMU HODNOCENII DOPRAVNÍCH STAVEB V CENTRECH MĚST
}

\author{
VARIANT APPROACHES TO ECONOMIC EVALUATION OF \\ TRANSPORT CONSTRUCTIONS IN THE CITY CENTERS
}

\author{
Jana Jíšová*,1, Josef Filip ${ }^{1}$, Tomáš Tichý1
}

*jana.jisova@pdprojekce.cz

'České vysoké učení technické v Praze Fakulta dopravní, Konviktská 20, Praha 111000

\begin{abstract}
Abstrakt
V rámci ekonomického hodnocení dopravních staveb se setkáváme s problémem hodnocení a parametrizace přínosů a nákladů specifických pro komplexnější stavby nebo úpravy prostranství v centru města. Některé metody je obtížné vhodně aplikovat na městské a technické stavby. Článek se zaměřuje na nalezení alternativního způsobu hodnocení vybraných staveb. Metody často souvisí s multikriteriální analýzou, jež vede na posuzování parametrů a způsobu určení váhy pro hodnocení.
\end{abstract}

\section{Klíčová slova}

Ekonomické hodnocení dopravních staveb, multikriteriální analýza (MKA), městské inženýrství, stavby v centru města

\begin{abstract}
Concerning the economic evaluation of transport constructions, there are problems with appraisal and parametrization of benefits and costs, especially for the complex constructions or modified areas in the city center. Some of the current methods are difficult to apply appropriately to city constructions or technical constructions. The article is focused on finding alternative ways to evaluate selected constructions. The methods are often connected to multi-criteria analysis, which leads to the assessment of parameters and methods of determining the weight of them for the evaluation.
\end{abstract}

\section{Key words}

Economic evaluation of transport constructions, multi-criteria analysis (MCA), city engineering, constructions in the city center

\section{1 ÚVOD}

V rámci ekonomického hodnocení staveb jsou v České republice jasně definované postupy a metody, jak hodnocení provádět. Ekonomické hodnocení je povinnou součástí záměrů projektů, jejich aktualizací a studií proveditelnosti [1]. Nejčastěji používanou metodou hodnocení je Cost-Benefit analýza (CBA) nebo také analýza nákladů a přínosů. Postupy hodnocení touto metodou jsou podrobně popsány v Rezortní metodice pro hodnocení efektivnosti projektů dopravní staveb [2]. Přesto, že je CBA uznávaný a certifikovaný nástroj, tak pro komplexní městské stavby není jeho použití vhodné a ani možné. Vyčíslení nákladů a prínosů projektů realizovaných v městském prostředí je komplikované a někdy dokonce nemožné. Výše zmíněná metodika připouští ve vybraných př́ípadech použití multikriteriální analýzy (MKA), ale tak jako tak musí být zpracována CBA.

Dopravními projekty v městském prostředí jsou chápany úpravy městských komunikací, křižovatek, vedení MHD a její preference, zklidňování dopravy, optimalizace pěších a cyklistických vazeb s ochranou těchto nejzranitelnějších účastníků provozu. Z hlediska změn v městském prostředí se jedná o komplexní problematiku, kde v našich návrzích, jež jsou stručně popsány v článku, dochází k podstatné modifikaci veřejného prostředí mající dopady na uváděné př́íklady (nová železniční stanice, výstavba budovy filharmonie atd.).

U těchto komplexních městských staveb, kde dochází ke změně mnoha parametrů, jak v dopravě, tak i ve využití území nebo jeho podobě, je použití tohoto hodnocení $\mathrm{v}$ první řadě nemožné a $\mathrm{v}$ druhé řadě 
nevypovídající. Vzniká proto požadavek na nalezení metodických postupů, které by dovolily hodnotit tyto složité městské stavby nebo úpravy, kde rozhodujícím parametrem nebudou pouze kapacity křižovatek a intenzity silniční dopravy.

\section{METODOLOGIE A PŘíSTUPY}

Jak je již zmíněno v úvodu, pro ČR je výchozím dokumentem pro ekonomické hodnocení silničních, železničních i vodních staveb Rezortní metodika [2], která zahrnuje možné přistupy pro posuzování. Základní hodnotící metodou je analýza nákladů a př́nosů, dále je možné ve specifických případech využití multikriteriální analýzy. Pro hodnocení silničních projektů se používá celosvětově uznávaný software HDM-4 (Harmonised System Approach to Road Management), který ale pracuje na principu analýzy nákladů a př́nosů.

Mezi další způsoby hodnocení projektů patří např́iklad modifikovaná verze MKA, tzv. multikriteriální analýza více subjektů (MAMCA - Multi Actor Multi Criteria Analysis), která zohledňuje především zainteresované subjekty a skládá se ze sedmi kroků [3]. Dalším druhem MKA je multikriteriální rozhodovací analýza (MCDA - Multi Criteria Decision Analysis) jedná se o rozhodovací nástroj, který se snaží najít dopady projektu. Stejně jako předchozí analýza zapojuje zainteresované strany. Výsledkem je seřazení variant od nejvíce preferované k té nejméně preferované. Existují již softwarové programy, které použivají tuto metodu hodnocení. Využívá především rozhodovací stromy, modelování nejistot a pravidlo očekávaného užitku [4], [5].

$\mathrm{V}$ prrípadech, kdy je těžké vyčíslit př́nosy ve finanční jednotce (monetizace), ale zato jsou jasně dány náklady, je vhodné využití analýzy efektivnosti nákladů (CEA-Cost Effectiveness Analysis). Porovnávají se varianty projektu na základě jednoho společného dopadu. Využití CEA je možné také v případě, že hledáme co nejméně nákladné řešení pro definované cíle [4].

Pro rozsáhlé projekty s makroekonomickým dopadem se využívá Analýza ekonomických dopadů (EiA-Economic Impact Analysis). Rozlišujeme dva prrístupy-vstupně/výstupní modely (Input/Output models) pro analýzu regionální ekonomiky a modely ekonomické simulace, kde se jedná o složitější ekonometrické a obecné modely rovnováhy [2].

Metoda DETR (Department Environment Transport Region) je založena na kvalitativním popisu projektu s možností dodat kvalitativní údaje. Výstupem je tabulka, kde jsou popsané hlavní dopady rozdělené do čtyř kategorií: ekonomické, environmentální, společenské a veřejné prostředky. Mezi hlavní nevýhody tohoto hodnocení patř́i neprovázanost kvalitativních a kvantitativních ukazatelů a hodnocení [2].

Mezi velmi rozšířené a známé analýzy patří tzv. SWOT analýza, která zohledňuje silné (Strengths) a slabé (Weaknesses) stránky projektu a jeho př́ležitosti (Opportunities) a hrozby (Threats). Cílem by mělo být podpořit silné stránky a př́ležitosti, a co nejvíce potlačit slabé stránky a hrozby projektu. Analýzou SWOT bychom měli najít hlavní změny, které nastanou vlivem realizace projektu. Součástí by mělo být i posouzení závěrů a jsou použity váhy pro určení pravděpodobnosti výskytu nebo důležitosti daného faktoru [2], [7].

Př́ístup s částečnou agregací se vyznačuje snahou odstranit nerovné socio-prostorové rozdělení efektů. Je tak zhodnocen vliv projektu na celkové blaho, ale zároveň je možné určit, jak férově jsou rozděleny př́nosy a náklady mezi dotčené skupiny [8].

Modely CGE (Computable General Equilibrium) jsou v dopravě používány především pro hodnocení dlouhodobých dopadů investic. Stejně jako u analýzy ekonomických dopadů neřeší tato metoda jednotlivé trhy, ale makroekonomii jako celek. Mezi nejnovější př́istupy patří tzv. FCGE (Financial Computable General Equilibrium), které kombinují skutečnou ekonomiku s volbou finančních aktiv a modulem $\mathrm{k}$ řešení změn v dopravních sítích [9], [10], [11].

Metoda systémového plánování (SP-Systemic Planning) je velmi vhodná pro komplexní problematiku, která zahrnuje velké množství nejistot. Je možné zahrnout jak tzv. tvrdé, tak i měkké přistupy operačního výzkumu. Kombinuje také metody zmíněné výše, např. CBA, CEA, SWOT nebo MKA. Může ale zahrnovat také teorii her, citlivostní analýzu nebo heuristiku kritických systémů (CSH-Critical Systems Heuristics) [12].

Poslední zmíněnou metodou jsou robustní rozhodovací přistupy (RDMA- Robust Decision Making Approaches), která je využívána především v situacích, kde je vysoká nejistota a poskytují tak analytickou podporu rozhodování. RDMA se nesnaží definovat budoucí stav na základě odhadu proměnných, ale snaží se nastínit možné stavy a poté učinit nějaké rozhodnutí, které je pro tyto stavy co nejspolehlivější [4].

Výběr metody je závislý na konkrétním projektu a dohodě všech zúčastněných stran, příp. Centrální komisi Ministerstva dopravy ČR, v prŕípadě, že je snaha využít jiné metody než definované v Rezortní metodice. 


\section{UPLATNĚNÍ METODIKY}

Ze zkušeností z praxe v rámci ekonomického hodnocení staveb přirozeně vyplynul požadavek na hledání jiných postupů a metodologií k hodnocení některých specifických staveb. Analýza nákladů a př́nosů (resp. HDM-4), jak je definována $\mathrm{v}$ Rezortní metodice [2] velmi dobře funguje $\mathrm{v}$ př́padech budování obchvatů nebo modernizace železnice, ale v rámci komplexnějších projektů, kdy dochází ke změně organizace křižovatek, cyklistické dopravy, peších vazeb atd., bývá velmi obtížné zohlednit všechny náklady a př́nosy, které s sebou projekt nese. Je velmi těžké zohledňovat takové aspekty staveb, které je obtižné nebo dokonce nemožné převést na finanční jednotky. I přesto, že mohou být velmi dobře popsány, nikdy jim nebude v hodnocení připisován takový význam jako monetizovaným položkám.

V praxi se projekty nejčastěji posuzují pouze z hlediska technické proveditelnosti, finanční náročnosti a pak propustnosti křižovatek (kapacity). Hodnocení bývá zaměřeno př́edevším na motorovou dopravu, příp. hromadnou dopravu. Ačkoli se jedná o důležité parametry, které není v žádném př́ípadě možné zanedbat, bylo by vhodné, kdyby do hodnocení mohly vstupovat také další parametry, které by měly vliv na celkové hodnocení projektu. V rámci mezioborové spolupráce s ekonomy, geoinformatiky, dopravními experty a dalšími experty vznikl metodický postup hodnocení projektu a je zobrazen stručným diagramem o šesti krocích na Obr. 1.

$\mathrm{Z}$ rešerše různých způsobů přístupů $\mathrm{k}$ hodnocení dopravních staveb vzešla myšlenka na vlastní hodnotící tabulku, která by dokázala postihnout všemožné parametry, jak tvrdé, které lze vyčíslit, tak i subjektivní (měkké). Možný způsob hodnocení je popsán v následující kapitole.

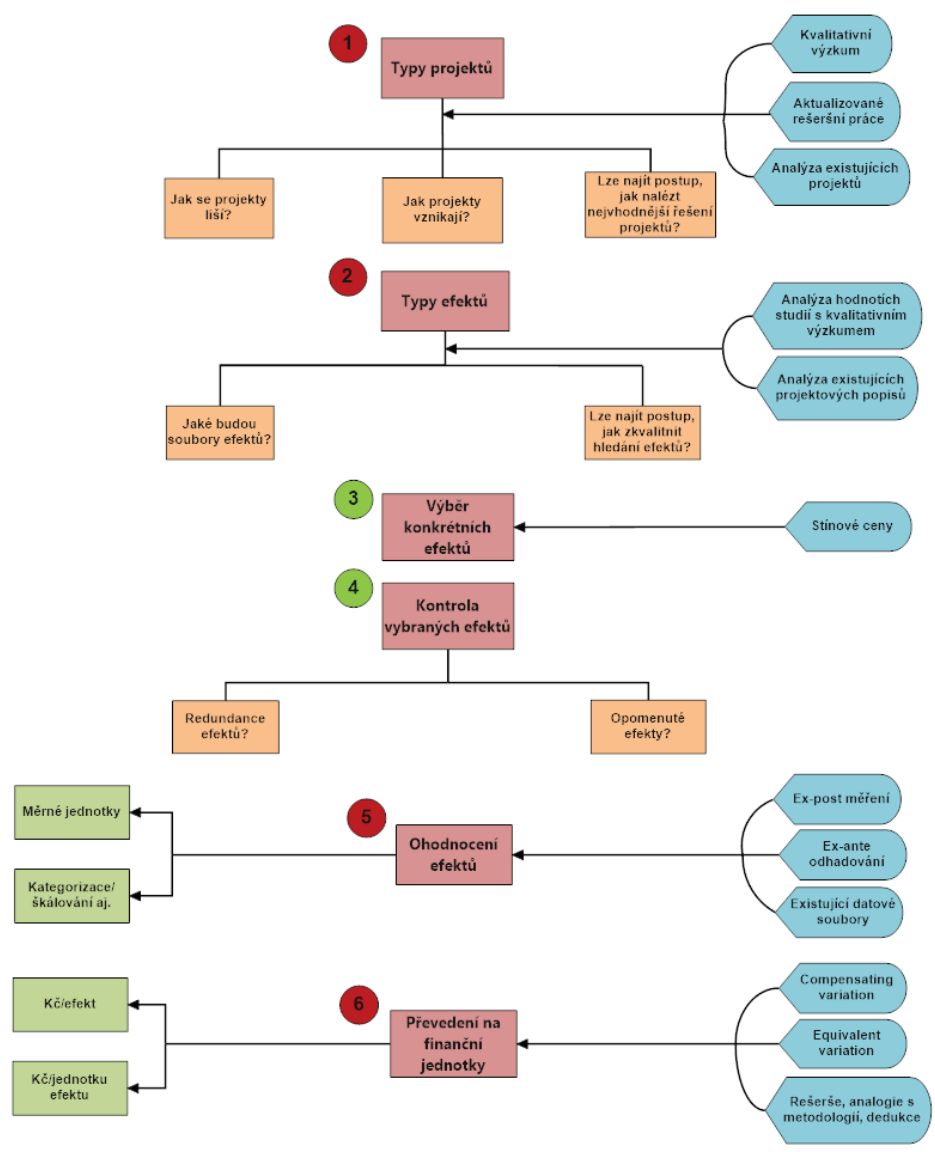

Obr. 1 Metodologický postup sestavení hodnocení. 


\section{VÝSLEDKY}

V záhlaví navrhované hodnotící tabulky budou ve sloupcích zobrazeny jednotlivé lokality, konkrétně místní komunikace typu B (sběrné), C (obslužné) a D1 (se smíšeným provozem), dále pak náměstí, obytné celky (např. sídliště) a uzly veřejné hromadné dopravy (VHD). Důležitým prvkem je sloupec váha kritéria, který bude určovat důležitost daného kritéria $\mathrm{v}$ projektu. Řádky budou zahrnovat jednotlivá kritéria (parametry/faktory) obecnějšího rázu. Tato základní kritéria je možné bliže specifikovat podkritérii (skladba dopravního proudu, parametry stání) a v některých prípadech je nutná ještě další úroveň zpřesnění (zbytná/nezbytná doprava, vysokoobrátková stání, vyhrazená stání, možnost dobíjení). V tabulce může být mnoho dalších hodnotících kritéríi, které jsou uvedeny v následujícím výčtu:

- intenzita:

- skladba dopravního proudu:

- zbytná,

- nezbytná;

○ intenzita;

○ ÚKD (Úroveň kvality dopravy);

- doprava v klidu:

$\circ$ rezidenti,

○ návštěvy;

○ parametry stání:

- vysokoobrátková,

- vyhrazená,

- možnost dobíjení;

- hromadná doprava:

- dostupnost,

- počet přpravených osob,

- bezpečnost:

- míra preference,

○ nehodovost,

○ pocit bezpečí;

- externality:

$\circ$ hluk,

- emise,

○ zeleň veřejného prostranství;

- $\quad$ pěší (viz praktický př́iklad);

- cyklisté:

- vedení s vozidly,

- vedení samostatně,

- vedení s chodci;

- telematika v dopravě:

○ navigace parkování,

- sledování poruch dopravních staveb,

○ řízení spotřeby elektrické energie,

- ř́zení dopravy;

- finanční hodnocení:
○ pořizovací náklady stavby,
○ náklady na údržbu stavby,
- zhodnocení pozemků.

Je zřejmé, že některá kritéria je možné přesně vyčíslit (intenzita, nehodovost, délky pěších cest atd.), takové parametry lze označit za tvrdé a je poměrně jednoduché je porovnávat. Některá kritéria jsou velmi subjektivní (pocit bezpečí, přehlednost) a jejich vyčíslení může být velkou výzvou a z toho vyplývá i obtížná možnost porovnání těchto parametrů a jejich př́ípadné obhájení, resp. podložení fakty.

Jako prrípadové studie byly vytipovány lokality plánovaných rozsáhlých projektů v Praze. Např́klad rekonstrukce mostu na Výtoni a s tím související zrrízení nové vlakové zastávky s vazbou na tramvajovou dopravu v Praze. Dále pak lokalita předpolí Hlávkova mostu, kde má vzniknout nová budova filharmonie, což úzce souvisí s rozsáhlými změnami v okolí mimoúrovňové křižovatky a přestupního uzlu Vltavská. 
Za první hodnocený parametr byly vybrány pěší vazby ve výše zmíněných lokalitách. Níže je zobrazena Tab. 1 hodnotící pěší vazby podle definovaných parametrů v oblasti Výtoně. Na následujícím Obr. 2 je možné vidět stávající pěší trasu od zastávky ke škole a nově navrženou pěší trasu.
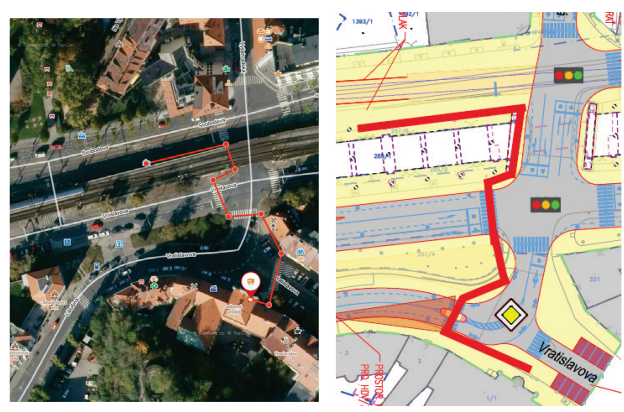

Obr. 2 Stávající trasa zastávka - škola.

Tab. 1 Pěší vazby škola-tramvajová zastávka (Výtoň) [14].

\begin{tabular}{|c|c|c|}
\hline Parametr & Stávající stav & Navrhovaný stav \\
\hline Délka trasy & $150 \mathrm{~m}$ & $131 \mathrm{~m}$ \\
\hline Počet přechodů pro chodce & 3 & 2 \\
\hline Odhadovaná doba pohybu & $4 \min 55 \mathrm{~s}$ & $3 \min 18 \mathrm{~s}$ \\
\hline Hlavní výhody & - návyk na stávající stav & $\begin{array}{l}\text { - nižší počet překonávaných přechodů; } \\
\text { - kratší vzdálenost; } \\
\text { - více variant cest; } \\
\text { - vyšší bezpečnost; }\end{array}$ \\
\hline Hlavní nevýhody & $\begin{array}{l}\text { - dlouhé (nenormové) přechody; } \\
\text { - delší doba na trase; } \\
\text { - více světelně řízených přechodů; }\end{array}$ & $\begin{array}{l}\text { - horší rozhledové poměry na nově } \\
\text { vzniklém přechodu; }\end{array}$ \\
\hline
\end{tabular}

\section{DISKUZE}

Výčet parametrů, který bude součástí hodnotící tabulky, by měl sloužit pro hodnocení projektů komplexních staveb realizovaných $\mathrm{v}$ rámci center měst. $\mathrm{V}$ článku je uveden pouze výčet parametrů, které budou součástí tabulky, a bude $\mathrm{k}$ nim nutné vyplnit př́ślušné hodnoty. V kontextu ekonomických hodnocení se bude jednat o princip multikriteriální analýzy. S odkazem na Rezortní metodiku [2] je v praxi velmi obtížné pro hodnocení využít vlastní hodnotící tabulku (podléhá schválení Centrální komise MD ČR). Bylo by proto vhodné, aby došlo k vycizelování jejího obsahu, aby zahrnovala všechny potřebné parametry, se kterými je možné se u takových staveb setkat, př́ípadně dala zpracovatelům alespoň nějakou volnost $\mathrm{k}$ odebrání nebo případnému dodání některých kritérií. Zároveň musí probíhat kontrola konzistence kritérií, tzn. aby nedocházelo k vícenásobnému započítání nákladů/přínosů některých parametrů nebo naopak, aby nedošlo k jejich opomenutí.

Další důležitou položkou je váha jednotlivých kritérií. Samotná multikriteriální analýza bývá mnohdy označována za značně subjektivní hodnotící nástroj, a to zahrnuje také určování vah jednotlivých parametrů. V následujících krocích tedy bude snaha hledat co nejlepší postupy pro určování vah kritérií. Výpočet vah bude pravděpodobně zahrnovat kombinaci více přístupů, aby byla zajištěna co největší objektivita. Např́klad se může jednat o sestavení žebříčku důležitosti jednotlivých kritérií v kombinaci s párovým srovnáváním. Je také důležité, v jaké formě bude po zainteresovaných stranách vyžadováno hodnocení daných kritérií-pouze slovní, procentuální, př́ípadně oboje. Vnímání slovních hodnocení je již samo o sobě velmi subjektivní, ale pro někoho mohou být pouze číselná hodnocení matoucí [13]. Toto jsou všechno proměnné, které je nutné vzít v úvahu, pro sestavení co nejobjektivnějšího hodnocení.

Na stručně demonstrovaném příkladu je možné vidět zhodnocení parametrů pomocí jednoduché tabulky $\mathrm{z}$ hlediska pěších vazeb, kde jsou porovnány parametry ve stávajícím a navrženém stavu a je tedy jasně vidět 
rozdíl mezi stavem před a po. Podobně mohou být zpracována i ostatní kritéria, kde bude vidět, jaké výhody/nevýhody přináší nově navrhovaná řešení.

$\mathrm{Na}$ dalším zvážení je použití jedné hodnotící tabulky, která bude zahrnovat přínos/náklad posuzované varianty oproti stávajícímu stavu (variantě bez projektu) nebo budou sestavovány dvě tabulky, kde bude možné vidět rozdíl mezi staveb bez a s projektem.

Otázkou jsou také jednotky, ve kterých bude porovnávání probíhat. Některá kritéria je možné převést na finanční jednotku nebo je možné porovnávat např́klad intenzity ve vozidlech za den (resp. voz/hod) nebo délku trasy v metrech.

\section{ZÁVĚR}

Stávající přistup k ekonomickému hodnocení je pro některé projekty velmi omezený a je proto analýzu nákladů a př́nosů obtížné aplikovat na některé složitější stavby realizované v centrech měst. Ze zkušeností z praxe proto vzešel požadavek na vytvoření alternativního způsobu hodnocení dopravních staveb, které mohou mít dopad na široké spektrum parametrů. V rámci zkoumání reálných projektů tak vznikl návrh hodnotící tabulky, která se nejblíže přibližuje stylu hodnocení pomocí multikriteriální analýzy. Pro zajištění odborného respektování této tabulky bude potřebné zaručit dostatečnou objektivnost hodnocení, což může být největší výzvou v návrhu variantního hodnocení dopravních staveb. Může také vyplynout potřeba kombinace s dalším způsobem hodnocení. Porovnávání jednotlivých kritérií je předvedeno na konkrétním př́ípadu navrhovaných změn z oblasti Výtoně, a to konkrétně na pěších vazbách v dané lokalitě. Dalším krokem by i dle uvedené metodologie bylo převedení kritérií, které to umožňují, na finanční jednotku.

Součástí navazujících prací bude nutné zajistit, že jsou zahrnuty všechny potřebné parametry, ale zároveň nebude docházet k vícenásobnému započítání některých nákladů nebo přínosů. Dále budou hledány nejvhodnější způsoby určování váhy jednotlivých kritérií, což bude součástí dalšího zkoumání.

\section{Poděkování}

Článek byl zpracován s podporou grantu SGS20/137/OHK2/2T/16 Chování pěších v terminálech VHD a na př́stupových komunikacích k nim.

\section{Použité zdroje}

[1] Prováděcí pokyny pro hodnocení efektivnosti projektů dopravní infrastruktury https://www.sfdi.cz/soubory/obrazky-clanky/metodiky/2017_provadeci_pokyny_efektivnost.pdf

[2] Rezortní metodika pro hodnocení efektivnosti projektů dopravních staveb https://www.sfdi.cz/soubory/obrazky-clanky/metodiky/2017_02_rezortni_metodika-komplet.pdf

[3] Macharis, C., Turcksin, L., \& Lebeau, K. (2012). Multi actor multi criteria analysis (MAMCA) as a tool to support sustainable decisions: State of use. Decision Support Systems, 54(1), 610-620. https://doi.org/10.1016/j.dss.2012.08.008

[4] Scrieciu, S. Ş., Belton, V., Chalabi, Z., Mechler, R., \& Puig, D. (2014). Advancing methodological thinking and practice for development-compatible climate policy planning. Mitigation and Adaptation Strategies for Global Change, 19(3), 261-288. https://doi.org/10.1007/s11027-013-9538-z

[5] Multi-criteria analysis: a manual. (2009). Department of Communities and Local Government: London.

[6] Transport notes (2005), Where to use cost effectivness techniques rather than cost benefit analysis https://assets.publishing.service.gov.uk/media/57a08c6b40f0b652dd001300/C21-trn-9-EENote2.pdf

[7] Hutáková, Z. (2014). Návrh strategie konkrétní společnosti [Diplomová práce]. Vysoká škola báňská.

[8] te Boveldt, G., Keseru, I., \& Macharis, C. (2020). Between fairness, welfare and feasibility: an approach for applying different distributive principles in transport evaluation. European Transport Research Review, 12(1). https://doi.org/10.1186/s12544-020-00428-4

[9] Kim, E., Hewings, G. J. D., \& Amir, H. (2017). Economic evaluation of transportation projects: An application of Financial Computable General Equilibrium model. Research in Transportation Economics, 61, 44-55. https://doi.org/10.1016/j.retrec.2016.09.002

[10] Frankenfield, J. (2021). General Equilibrium Theory. Investopedia. Retrieved February 17, 2021, from https://www.investopedia.com/terms/g/general-equilibriumtheory.asp\#: :text=General\%20equilibrium $\% 20$ theory $\% 2$ C $\% 20$ or $\% 20$ Walrasian,in $\% 20$ the $\% 201$ ate $\%$ 2019 th\%20century.

[11] Kř́stková, Z. (2009). Simulace dopadu nástrojů zemědělské politiky a českou ekonomiku v kontextu obecné rovnováhy [Disertační práce]. Česká zemědělská univerzita v Praze. 
[12] Leleur, S. (2007). Systemic planning: Dealing with complexity by a wider approach to planning. E:CO, 9(1-2), 2-10.

[13] Emrouznejad, A., Grafakos, S., Flamos, A., Oikonomou, V., \& Zevgolis, D. (2010). Multi-criteria analysis weighting methodology to incorporate stakeholders' preferences in energy and climate policy interactions. International Journal of Energy Sector Management, 4(3), 434-461. https://doi.org/10.1108/17506221011073851

[14] Povolný, J. (2021). Hodnocení vhodnosti vybraných staveb veřejných prostranství v Praze [Bakalářská práce]. ČVUT v Praze. 